Volume 3, Number 2, 2017

\title{
Microwave Device for Obtaining Extracts from Plant Materials
}

\author{
Natalia Volgusheva, Kateryna Heorhiiesh", Leonid Boshkov \\ Odessa National Academy of Food Technologies, Ukraine, 65082, Odessa, Dvoryanska St., 1/3
}

(C) 2017 Authors. Published by Lviv Polytechnic National University.

Received: October 11, 2017. Revised: November 02, 2017. Accepted: November 13, 2017.

\begin{abstract}
A method for obtaining biopesticides from plant materials based on application of a microwave electromagnetic field in the process of extraction is being studied. The article presents results of an experimental study of the efficiency of microwave extracts. The expediency of extracting biologically active substances in a microwave field is shown. The application of the method makes it possible to proceed to the production of large volumes of preparations and to reduce the volumes of chemical agents. A device is proposed for implementing this method. In order to increase the productivity, it is reasonable to develop an extractor of continuous action, and for this purpose the input and output channels should be designed so that their length corresponds to the length of the below cutoff waveguide that provides operation safety of the personnel working with the microwave device. For transfer of electromagnetic energy, it is rational to use horn antennas, and diameter of the channel through which raw materials with extractant pass should not exceed two depths of penetration taking into account the effect of thermal conductivity.
\end{abstract}

Keywords: biopesticides; microwave field; plant materials; efficiency; microwave screw extractor.

\section{Introduction}

The topicality of increasing the degree of biopesticides application is obvious; however this practice is still insufficiently used. The biopesticides introduction is impeded by the current technologies for obtaining extracts from vegetative raw materials. The technologies are characterized by long duration of the process and high economic expenditure as well as the insufficient knowledge of properties of the obtained vegetative extracts meant to be biopesticides. Thus, there is a necessity to develop a new effective method for obtaining vegetative extracts. One of prospective ways of extraction is extracting in a microwave (MW) field. In the research carried out earlier [1] the state of the issue of obtaining extract from vegetative raw materials and their application as biopesticides has been studied; in addition, the efficiency of extraction in a microwave field has been shown: the application of microwave technologies allowed us to considerably reduce the duration of biologically active substances extraction from vegetative raw materials (for example, duration of MW extraction was reduced by 15 minutes and that of a Soxhlet extraction - by 3 hours). The reduction of extraction duration in a microwave field was confirmed by numerous studies [2-6]. The data [2] indicate that the microwave processing halved the duration of the process of arabinogalactan (AG) extraction from the milled larch wood, and at the same time it increased AG output and purity; on the other hand, the duration of conventional extraction processes took some hours. Many authors underline that the microwave processing is energy and economic efficient in addition to the essential reduction of the extraction process duration. For example, in [3] it was shown that the use of microwave energy was beneficial in economic and ecological aspects in comparison with conventional (thermal) ways of heating. The laboratory studies and calculations [4] have shown that MW extraction from newly gathered raw material without mechanical processing, solvents and water addition to it results in 2-3-fold increase in the output of the extracted substances, almost 10-fold decrease in the process duration, decrease in the specific power inputs by over $50 \%$, obtaining products of higher quality, ensuring ecological cleanliness of the process in comparison with conventional methods. In some studies [57] attempts to present physical processes of a microwave field interaction with a vegetative material, which cause an

* Corresponding author. Email address: georgiesh.kat@gmail.com

This paper should be cited as: N. Volgusheva, K. Heorhiiesh, L. Boshkov. Microwave device for obtaining extracts from plant materials. Energy Eng. Control Syst., 2017, Vol. 3, No. 2, pp. 43 - 46. https://doi.org/10.23939/jeecs2017.02.043 
essential intensification of biologically active compounds output, have been made. The available data enabled researchers to recommend microwave processing as a technology for extraction of biologically active compounds from vegetative materials. However, the technology requires the detailed analysis for obtaining recommendations on how to run the process and develop a device for its realization.

\section{Description of the object that is analyzed and of its innovation research model}

Having analyzed the state of the matter of obtaining biopesticides from vegetative raw materials under the conditions of microwave field action the following tasks have been formulated:

1. To continue development of MW extraction method.

2. To examine the efficiency of the obtained extracts meant to be biopesticides.

3. To design a microwave extractor of continuous action.

The aim of the study was to develop a method for obtaining biopesticides from vegetative raw materials based on application of a microwave electromagnetic field in the process of extraction, and developing a device for its implementation. For obtaining the extracts, a mix of water (as a extractant) and a vegetative material was located in the working chamber of a microwave laboratory device where it was processed in a microwave field. In addition, the duration of the process and magnetron output capacity varied. The efficiency of the obtained extracts as means for pest control was tested on leaves of a fig tree (Ficus carica L.) infected with red spider mite (Tetranychus urticae Koch.). The evaluation of all experimental groups was carried out with use of nonparametric rank criterion for Kruskal - Wallis multiple comparisons.

The application of a microwave field at the stage of obtaining extracts meant for biopesticides production allows essentially reducing their production time. Therefore, there is a possibility to process great volumes of vegetative raw materials including various production wastes (onion, garlic peels, etc.) for a short period of time and it can be annually renewed, and to use the obtained preparations as a mean of plant protection. To implement the microwave method for obtaining extracts at large-scale enterprises, it is necessary to make a microwave screw extractor which circuit design was proposed in the given study. The efficiency of biopesticides action was tested on the extracts from onion peelings (Allium cepa) and common wormwood (Artemisia vulgaris L.). The leaves of cultivated fig tree (Ficus carica L.) damaged by red spider mite (Tetranychus urticae Koch.) were treated with the obtained extracts. To obtain reliable results, the treatment was made in fivefold repetition.

Vegetative raw materials (common wormwood and onion peelings) were crushed, filled in with water and then extraction in a microwave field at different modes was carried out. After obtaining the extracts the leaves of cultivated fig tree damaged by red spider mite were treated with the obtained extracts. For estimation of the damage degree the estimation in points was used: 0 - there is no damage at all, 1 - insignificant single damages, 2 insignificant damages all over the leaf surface, 3 - considerable damages in some leaf zones, 4 - considerable damages all over the leaf surface, 5 - a completely damaged leaf. In the end of the experiment the mean point $n$ (Table 1) was calculated. In Table 1 weight of raw materials: $1 \mathrm{~g}$; weight of water: $60 \mathrm{~g} ; P$ - magnetron output capacity $\tau$ - duration of treatment, $t_{f}$ - the material mean final temperature. The material initial temperature: $t_{\text {inl }}=16{ }^{\circ} \mathrm{C}, p-$ the level of validity calculated using the Kruskal-Wallis nonparametric rank multiple comparison test and $\chi^{2}$.

Table 1. Characteristics of extracts from plant materials.

\begin{tabular}{|c|c|c|c|c|c|c|c|c|c|}
\hline Experiment No & 1 & 2 & 3 & 4 & 5 & 6 & 7 & 8 & 9 \\
\hline $\boldsymbol{P}, W$ & \multicolumn{3}{|c|}{90} & \multicolumn{3}{|c|}{360} & \multicolumn{2}{|c|}{600} & check \\
\hline$\tau, c$ & 30 & 60 & 180 & 30 & 60 & $\frac{360}{60}$ & 30 & 600 & \\
\hline \multicolumn{10}{|c|}{ Plant material: onion peelings } \\
\hline$t_{f},{ }^{\circ} \mathrm{C}$ & 27 & 36 & 54 & 50 & 77 & - & 98 & - & 16 \\
\hline$n$ & 0.8 & 0.8 & 0.4 & 0.6 & 0.4 & - & 0.4 & - & 2.5 \\
\hline Mean rank & 20.1 & 17.3 & 15.4 & 18.6 & 15.4 & - & 15.4 & - & 23.7 \\
\hline$\chi^{2}$ & \multicolumn{9}{|c|}{16.74} \\
\hline$p$ & \multicolumn{9}{|c|}{0.019} \\
\hline \multicolumn{10}{|c|}{ Plant material: common wormwood } \\
\hline$t_{f},{ }^{\circ} \mathrm{C}$ & 25 & 35 & 53 & 48 & 72 & 89 & 93 & 107 & 16 \\
\hline$n$ & 0.8 & 0.8 & 0.6 & 0.8 & 0.6 & 0.4 & 0.4 & 0.4 & 3 \\
\hline Mean rank & 25.4 & 25.4 & 22.8 & 26.9 & 21.3 & 18.7 & 18.7 & 18.7 & 29.5 \\
\hline$\chi^{2}$ & \multicolumn{9}{|c|}{18.31} \\
\hline$p$ & \multicolumn{9}{|c|}{0.032} \\
\hline
\end{tabular}


The results presented in the table indicate quite high level of validity. The essential difference between different experimental groups can be seen. The data indicate more effective treatment with the extracts obtained under the influence of a MW field in comparison with the check treatment.

The analysis of the research data on obtaining the extracts showed that red spider mite was completely destroyed in five repetitions of the experiment at the following mode parameters of microwave extraction: duration of extraction not less than $30 \mathrm{~s}$ with final temperature over $80{ }^{\circ} \mathrm{C}$. The same result was obtained at temperature over $100{ }^{\circ} \mathrm{C}$; however in this case the energy expenses increased, and for that reason its application was irrational. The extracts which final temperature did not exceed $55^{\circ} \mathrm{C}$ did not give steady results (insignificant damages of the leaf surface were observed).

For developing the circuit design of the microwave extractor intended for extraction of substances biologically active in relation to plant pests the, following principles were taken into account:

- In order to increase productivity, it is reasonable to design an extractor of continuous action, and for that input and exit channels should be calculated so that their length corresponds to the length of the below cutoff waveguide that provides operation safety of the personnel who deal with the microwave device.

- For transfer of electromagnetic energy it is rational to use horn antennas, and diameter of the channel through which raw materials with extractant pass should not exceed two depths of penetration taking into account the effect of thermal conductivity. The given value can be determined in accordance with [8].

\section{A microwave extractor design}

An embodiment of the circuit design of the microwave horizontal screw extractor has been presented in Fig. 1. The extractor of continuous action contains the devices of loading, unloading, screw movement of vegetative raw materials and their processing using extractant. The screw blades should be made of a radioparent material and be perforated. In the top part of the column the vegetative raw materials are squeezed, and for that there is a squeezer cone (it is not presented in Fig. 1).

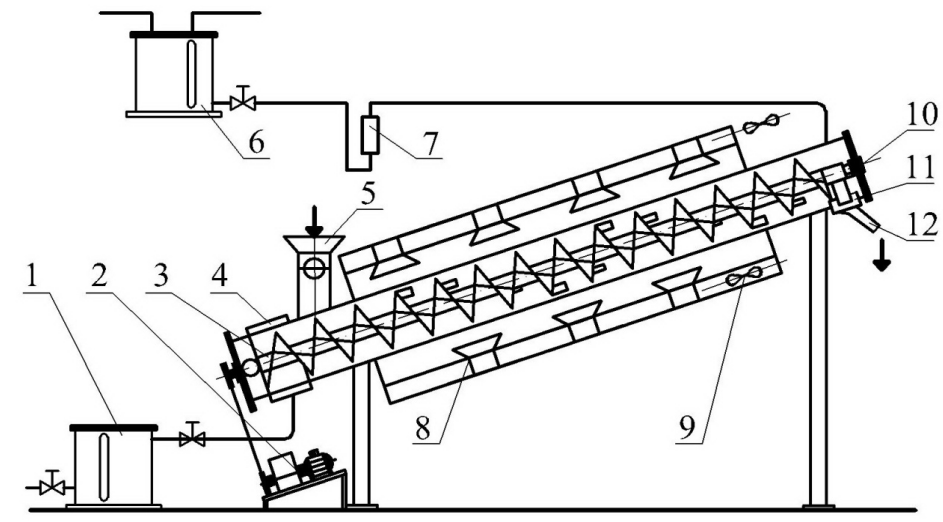

Fig. 1. The screw microwave extractor design. 1 - the extract collector, 2 - the drive, 3 - the screw, 4 - the sieve belt, 5 - a loading bunker, 6 - the container with extractant, 7 - a rotameter, 8 - the magnetrons with horn antenna, 9 - a fan, 10 - a stopcock, 11 - a kickoff blade, 12 - a tray.

A vegetative raw material is loaded from below, and the speed of its lifting is regulated by speed of screw rotation in a backflow to an extractant. The extractant is fed into the working channel by the dosing unit. Flowing downwards through the vegetative raw materials the extractant is filled with extracting substances and moistens a dry vegetative raw material. The extractor should operate with different kinds of vegetative material, and at the same time it should provide regulation of screw rotation speed and the extractant flow so that for each case an optimal output of biologically active substances can be achieved. As the above-mentioned experimental data shows the duration of extraction, even for initially dry raw material, can be less than a minute, and that allows designing a single-pass screw extractor of high-performance. In order to determine the necessary number of magnetrons thermal calculations have to be carried out. At a flow rate of $\mathrm{G}=0.01 \mathrm{~kg} / \mathrm{s}$ and the final temperature $t_{f}=80{ }^{\circ} \mathrm{C}$ (the initial $t_{\text {inl }}=15^{\circ} \mathrm{C}$ ) and taking into account the working section coefficient of efficiency which depends on dielectric properties of a processed material, and by the results of our experiments it should be not less than $\eta \leq 0.8$ (the extractant - water), four magnetrons with the capacity of $1 \mathrm{~kW}$ each is required. 


\title{
4. Conclusion
}

It has been established that the method for obtaining biopesticides based on extraction of biologically active substances in a microwave field is characterized by efficiency and rapidity. That gives the possibility to begin manufacture of great quantity of the preparations necessary for protection of cultural plants and to reduce quantity of chemicals which are usually used. In compliance with the obtained data for obtaining effective extracts at optimal energy consumption, the temperature of the process should be at the level of $80{ }^{\circ} \mathrm{C}$. The circuit design of the microwave extractor intended for realization of the MW extraction method has been proposed.

\section{References}

[1] Boshkova I.L. (2010). Rationality of microwave extraction of biologically active substances as the natural pesticides with the plant raw materials / I.L. Boshkova, N.V. Volgusheva, S.G. Kolomiuchuk, T.Yu. Dementyeva // Equipment and technologies of food production. Donetsk: DonNUET, Issue 24, pp. 146-153. (in Ukrainian)

[2] Kuznetsova S.A. (2005). Intensification of arabingalactane water extraction process from larch / S.A. Kuznetsova, A.G. Mikhailov, G.P. Skvortsov // Chemistry of plant raw materials. No. 1, pp. 53-58. (in Russian)

[3] Shavshukova S.Yu. (2003). Intensification of chemical processes by means of microwave radiation: abstract of dissertation wrok... Cand. of Techn. Sci. / S.Yu. Shavshukova. UFA: NIIReaktiv,. 24 p. (in Russian)

[4] Golubchikov L.G. (2006). Mobile microwave frequency extractor / L.G. Golubchikov, N.I. Malyh, A.I. Markolia, M.L. Subbotin // Issues o nuclear science and engineering. Thermonuclear synthesis. No. 1. pp. 80-86. (in Russian)

[5] Pat. RU 2216574 C2. Technique for valuable substances extraction from the plant raw material by means of microwave frequency energy / Markoliya A.I., Malyih N.I., Golubchikov L.G. i dr. No. 2002100236/13, No. 2002100236/13, published on 11.01.2002. (in Russian)

[6] Pat. RU 2254159 C2. Technique for biological raw material extraction / Kvasenkov O.I., Tyuryukov A.B: 2003125092/15, published on 15.08.2003. (in Russian)

[7] Lozhkina G.A. (2007) Influence of various factors on the extraction process of balsam poplar buds / G.A. Lozhkina, E.V. Isaeva, T.V. Ryazanova // Chemistry of plant raw materials. No. 2, pp. 51-54. (in Russian)

[8] Boshkova I.L. (2012). Analytical research of temperature field in the body with continuous acting heat sources / I.L. Boshkova, T.Yu. Dementeva // Refrigerating engineering and technology. - Odessa: ODAH, No. 1, pp. 42-45. (in Russian)

\section{Мікрохвильовий пристрій для отримання екстрактів із рослинних матеріалів}

\author{
Наталія Волгушева, Катерина Георгієш, Леонід Бошков \\ Інститут холоду, кріотехнологій та екоенергетики ім. Мартиновського Одеської національної академії \\ харчових технологій, вул. Дворянська, 1/3, м. Одеса, 65082, Україна
}

\section{Анотація}

Вивчається метод отримання біопестицидів з рослинної сировини, заснований на застосуванні мікрохвильового електромагнітного поля в процесі екстрагування. Наведено результати експериментального дослідження ефективності мікрохвильових екстрактів. Показана доцільність екстрагування біологічно активних речовин у мікрохвильовому полі. Застосування методу дає можливість перейти до виробництва великих обсягів препаратів і знизити обсяги хімічних засобів. Запропоновано пристрій для реалізації даного методу. Для збільшення продуктивності доцільно конструювати екстрактор безперервної дії, при цьому канали входу і виходу повинні бути розраховані так, щоб їх довжина відповідала довжині позамежного хвилеводу, що забезпечує безпеку роботи персоналу 3 мікрохвильовим пристроєм. Для передачі електромагнітної енергії раціонально використовувати рупорні антени, а діаметр каналу, по якому проходить сировина з екстрагентом, не повинен перевищувати дві глибини проникнення з урахуванням ефекту теплопровідності.

Ключові слова: біопестициди; мікрохвильове поле; рослинна сировина; ефективність; шнековий екстрактор. 